\title{
DEVELOPMENT OF GRANULAR UREA-ZEOLITE SLOW RELEASE FERTILIZER USING INCLINED PAN GRANULATOR
}

\author{
Pisey Hoeung1*, Yazid Bindar'1, Semuel Pati Senda ${ }^{2}$ \\ ${ }^{1}$ Research Group of Energy and Chemical Engineering Processing System \\ Department of Chemical Engineering, Faculty of Industrial Technology \\ Institut Teknologi Bandung, Jalan Ganesha 10 Bandung 40132 \\ ${ }^{2}$ Department of Chemical Engineering-Faculty of Industrial Technology \\ Institut Teknologi Sepuluh November, Kampus ITS Sukolilo, Surabaya \\ Email : hoeung_pisey@yahoo.com
}

\begin{abstract}
Slow release fertilizers (SRFs) are so crucial in improvement of agriculture productions. To increase urea fertilizer effectiveness and efficiency, the product could be modified in the form of SRFs. The objective is to conduct slow release urea fertilizer. During granulation, particle sizes of urea and natural zeolite mixture $(50,60$ and 80 mesh), binder solution with different percentage ( $2 \%$ to $10 \%)$ of starch, and clay additives $(5 \%, 7.5 \%$, and $10 \%)$ were used. The obtained granule was further analyzed using percolation reactor to determine the slow release rate. Leachate from reactors was collected, by using UV-visible spectrophotometric method, concentration of dissolved urea was determined. The granule size of 3-4 $\mathrm{mm}$, the urea-zeolite mixture particle size of 60 -mesh, the percentage of clay addition in the granulation process of $7.5 \%$, the percentage of starch addition in binder solution of $3 \%$ are selected to be the best in term of the roughness of the granules, economic aspects, and slow release rate. In addition, it is proportionally defined the release time of nutrient from experiment and from simulated program is at least for three months which is plenty of time for crops, especially for rice.
\end{abstract}

Key words: Slow Release Fertilizer, Zeolite, Urea, Inclined pan granulator

\begin{abstract}
Abstrak
Slow release fertilizers (SRFs) memiliki peranan yang sangat penting dalam peningkatan produksi pertanian. Untuk meningkatkan efisiensi dan efektifitas pupuk urea, produk pupuk bisa dimodifikasi dalam bentuk SFRs. Tujuan dari penelitian ini adalah untuk membuat slow release urea fertilizer. Selama proses granulasi, digunakan ukuran partikel campuran urea dan zeolit alam (50, 60 dan 80 mesh), cairan perekat dengan persentase yang berbeda $(2 \%$ sampai 10\%) starch, dan tambahan tanah liat (5\%, 7,5\%, dan 10\%). Butiran-butiran (granul) yang diperoleh selanjutnya dilakukan analisis menggunakan reaktor perkolasi digunakan untuk menentukan laju slow release. Leachate dari reaktor dikumpulkan, kemudian konsentrasi urea terlarut dapat diketahui dengan menggunakan metode spektrofotometri UV-Vis. Granul 3-4 mm, ukuran 60 mesh campuran antara urea dan zeolit, persentasi penambahan tanah liat dalam proses granulasi sebesar $7,5 \%$, dan persentasi penambahan starch dalam larutan perekat sebesar 3\% menunjukkan hasil yang terbaik untuk tingkat kekasaran butiran, aspek ekonomi dan menunjukkan pelepasan nutrisi lambat. Secara proporsional dapat dikatakan bahwa waktu pelepasan nutrisi yang diperoleh dari percobaan dan simulasi program, setidaknya untuk tiga bulan sangat cukup untuk tanaman, khususnya untuk padi.
\end{abstract}

Kata kunci: Slow release fertilizers, Zeolit, Urea, granulator panci miring.

* corresponding author 


\section{Introduction}

Crop production yield especially rice, in Cambodia are considerably low. This is because of the loss of soil fertility and poor soil management, poor fertilizer application which causes the loss in soil structures and soil texture, imported inorganic fertilizers, lack of irrigation system, high cost of fertilizers and so on. To increase rice production in this country, extensive use of efficient fertilizers is needed (Mund and Bunthan, 2006).

Zeolite, porous minerals with high cation-exchange capacity, can help control the release of plant nutrients in agricultural systems. Zeolite also can free soluble nutrients already in soil for the use by plants, and may improve soil fertility and water retention (Millan Et. La., 2008). Zeolite is an important resource in agriculture, owing to its water and ammonium retention capacity and because it helps to reduce nitrogen loss. In addition, it has been verified that when mixed with nitrogen, phosphorous, and potassium compounds, zeolite enhances the action of such compounds as slow release fertilizers, both in horticultural and extensive crops. Therefore, zeolite acts as a slow release fertilizer, giving the plant access to water and nutrients for longer, which results in a significant saving in water resources and reducing the amount of fertilizer to be applied, thus helping to decrease the amount of water used per crop and the contamination of aquifers resulting from the overuse of fertilizers (Perez et. al., 2008). Zeolite can also act as water moderators, in which they will adsorb up to $55 \%$ of their weight in water and slowly release it under plant demand. This property can prevent root rot and moderate drought cycles. Therefore an application of zeolite will enhance the plant growth and development by reducing the loss of nutrients (Polat et. al., 2004). Besides those benefits, zeolite is a porous sponge structured mineral that can be used as water purifier, drying agent, as well as the processing agent for food and medicine. It also contains inorganic fertilizer such as calcium, iron, magnesium, and potassium. Therefore, when we mix the zeolite with the cultivated land, it will improve the soil properties. However, because it contains neither nitrate nor phosphate nor organic nutrient matters, it cannot efficiently perform its potential efforts in agriculture. Zeolites may hold water up to $60 \%$ of their weight due to high porosity of the crystalline structure (Leggo and Ledesert, 2009). Furthermore, high absorption capacity makes zeolites a carrier of agriculture pesticides (Mumpton, 1999). Unlike other soil amendment (e.g. lime) zeolite does not break down over time but remains on the soil to improve nutrients retention. Therefore, its addition to soil will significantly reduce water and fertilizer costs by retaining beneficial nutrients in the root zone. The porous structure of natural zeolite helps to keep the soil aerated and moist as well as active for a long time.

Urea is used in many ways to provide $\mathrm{N}$ nutrition for plant growth and it is the most important nutrient for plants. Urea hydrolysis is a rapid process, typically occurring within several days after application. More than $90 \%$ of world production of urea is destined for use as a nitrogen-release fertilizer. In the past decade urea has surpassed and nearly replaced ammonium nitrate as a fertilizer. Urea is used most popularly as a fertilizer due to its high level of nitrogen. It has the highest nitrogen content, equal to 46 percent. The nitrogen makes the urea water-soluble and easy to mix in soil (Ariathilaka et. al., 2008).

Currently, the use of slow release fertilizer (SRF) is a new trend to reduce fertilizer consumption and to minimize environmental pollution. Slow release fertilizers are made to release their nutrient contents gradually and to coincide with the nutrient designed of a plant. Also, slow release fertilizers are excellent alternatives to soluble fertilizers. Because nutrients are released at a slower rate throughout the season, plants are able to take up most of the nutrients without wasted by leaching. A slow release fertilizer is more convenient, since less frequent application is required. Fertilizer burn is not the problem with slow release fertilizers even at high rates of application; however, it is still important to follow application recommendations (Marylang, 2006). Slow release fertilizers may be more expensive than soluble types, but their benefits outweigh their disadvantages.

This research, the main objective is to develop a slow release fertilizer formulation based on urea-zeolite mixture by using inclined pan granulator. The effects of urea, zeolite particle size, clay additive and starch content of the binder solution on the slow 
release rate are studied. Furthermore, the observed urea release rate was compared with numerical analysis results from simulated program using MATLAB to figure out the release time.

\section{Methodology}

Natural Zeolite is obtained from Malang region in East Java and urea fertilizer is supplied by P.T. Kaltim in Bontang, East Kalimantan. Clay is purchased from the center for ceramic research of the ministry of industry in Bandung and screened to obtain the desired particle sizes. Commercial Tapioca starch (brand name of Rose Brand) was used.

The experimental setup was designed according to Devotta et al., (2006) in which a vertical glass column reactor is used (Figure 1). Deionized water is continuously supplied from the tank on the top at a flow rate 8 $\mathrm{mL} / \mathrm{min}$ and flow under gravity. Reactors were set up to perform the tests in duplicate and three tests of different samples were performed at the same time with different granule types. $16 \mathrm{~g}$ of slow release urea fertilizer was placed inside each reactor and the leachate was collected to determine the urea concentration using the UV-visible spectrophotometric method.

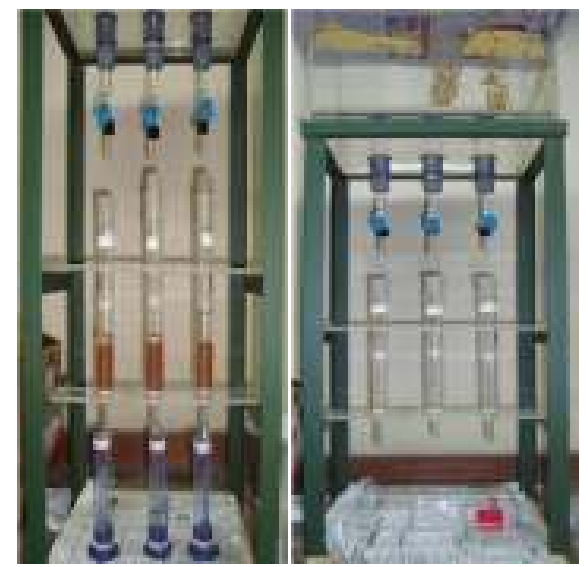

Figure 1. Experimental setup of the percolation reactor for nutrient uptake

The inclined pan batch granulator is used to produce granules in this study. This pan granulator consists mainly a inclined disk with $1 \mathrm{~m}$ diameter and $13 \mathrm{~cm}$ rim height (Figure 2).

In order to produce the mixture of urea and zeolite, a vertical batch mixer is employed. Urea and zeolite are blended in mixer with the same particle sizes of 50, 60 and 80 mesh. Also, in every mixing process the same ratio of $1: 1$ of both materials is applied. As we do not focus on this processing, we assume that this used mixture is homogeneous. However, the mixture of urea and zeolite is manually mixed with clay in different percent of $5 \%, 7.5 \%$ and $10 \%$ in term of finding the granule roughness.

Binder solution is one of the most crucial factors in granulation process. Tapioca starch does not dissolve in cool water but it does dissolve partly in warm water. In this case, binder solution is obtained by mixing the tapioca starch with the 1:1 ratio of cool and warm water around 50-60 C. concentration of binder solution was varied from $2 \%$ to $10 \%$.

In order to calculate the concentration of urea, leachate from each reactor were collected every 30 minutes for 6 hours. $1 \mathrm{~mL}$ of each leachate was placed in $10 \mathrm{~mL}$ test tube and mixed with $1 \mathrm{~mL}$ of $0.230 \mathrm{M}$ Hydrochloric acid $(\mathrm{HCl}), 1 \mathrm{~mL}$ of $1 \times 10^{-4} \mathrm{M}$ Potassium bromate $\left(\mathrm{KBrO}_{3}\right), 1 \mathrm{~mL}$ of $6 \times 10^{-4} \mathrm{M}$ Methyl Orange and deionized water to get the $10 \mathrm{~mL}$ of solution. The solution was then analyzed in the spectrophotometer with a wavelength of $505 \mathrm{~nm}$.

To get the maximum benefit, fertilizers especially urea is being produced in spherical shaped granules. The aim of this modeling is to determine the release time as well as the accumulative mass fraction of urea from the granule. The release time and accumulative mass fraction from the granule are simulated using mass diffusion equations and found computationally by integrating the initial and boundary value problems using a finite differential scheme. The water penetration into the granule and urea mass fraction release, both take place due to the diffusion process. The partial differential equations which describe the unsteady mass transfer due to diffusion in a three dimensional space is presented in equation 1 .

$$
\frac{\partial Y_{u}}{\partial t}+\left(v_{r} \frac{\partial Y_{u}}{\partial r}+v_{\theta} \frac{1}{r} \frac{\partial Y_{u}}{\partial \theta}+v_{\phi} \frac{1}{r \sin \theta} \frac{\partial Y_{u}}{\partial \phi}\right)=D_{a b}\left(\frac{1}{r^{2}} \frac{\partial}{\partial r}\left(r^{2} \frac{\partial Y_{u}}{\partial r}\right)+\frac{1}{r^{2} \sin \theta} \frac{\partial}{\partial \theta}\left(\sin \theta \frac{\partial Y_{u}}{\partial \theta}\right)+\frac{1}{r^{2} \sin ^{2} \theta} \frac{\partial^{2} Y_{u}}{\partial \phi^{2}}\right)+R_{u}
$$




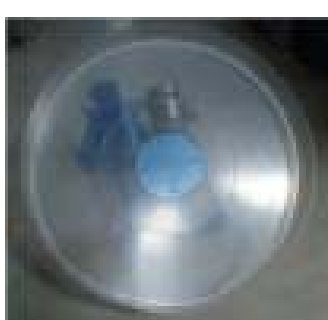

(a)

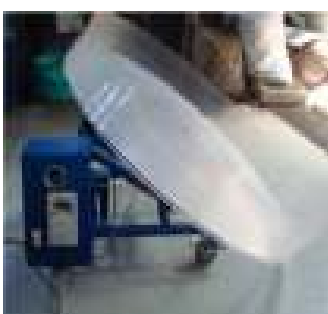

(b)

Figure 2. Inclined Pan Granulator (a) front view (b) side view

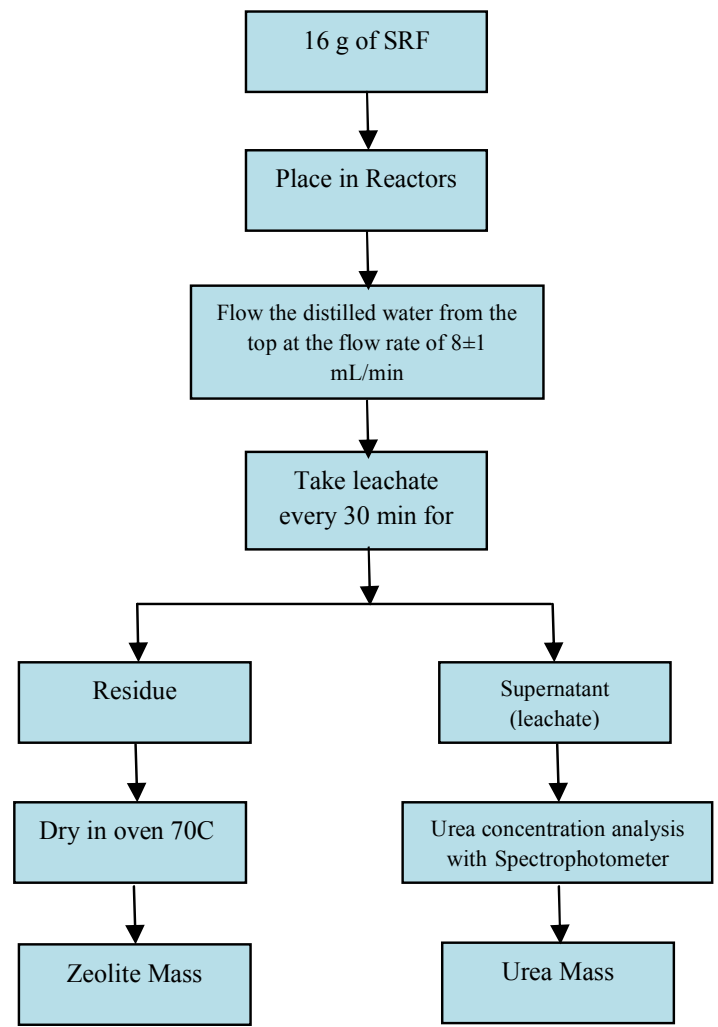

Figure 3. Sample analysis

$\frac{\partial Y_{u}}{\partial t}=D_{a l}\left(\frac{1}{r^{2}} \frac{\partial}{\partial r}\left(r^{2} \frac{\partial Y_{u}}{\partial r}\right)\right) \quad$ or $\quad \frac{\partial Y_{u}}{\partial t}=D_{a l}\left(\frac{2}{r} \frac{\partial Y_{u}}{\partial r}+\frac{\partial^{2} Y_{u}}{\partial^{2}}\right)$

The initial condition is $\mathrm{Y}_{\mathrm{u}}(\mathrm{r}=0, \mathrm{t}=0)=\mathrm{Y}_{\mathrm{u} 0}$

As soon as the granule is in contact with water flowing from the top, release of nutrient will start and we assume that there is no reaction in this case so that rate of reaction is negligible. The movement of nutrients is assumed to be one dimensional, radially symmetric from the outer circumference toward the center. The urea diffusion coefficient is $D_{a b}$, which is the same in all positions. The mass diffusion partial differential Eq. (1) in the present case may be written as Eq. (2) where the mass fraction is assumed that everywhere in the granule to be $Y_{0}=0.5$. The boundary condition is $Y_{u}(r=R$, $\mathrm{t}>0$ )

Mass flux: $\mathrm{m}_{\mathrm{u}, \mathrm{r}}=-\left.\rho \cdot \mathrm{D}_{\mathrm{ab}} \cdot \frac{\partial Y_{u}}{\partial r}\right|_{R}=\rho \cdot \mathrm{k}_{\mathrm{u}} \cdot\left(\mathrm{Y}_{\mathrm{u}, \infty}-\mathrm{Y}_{\mathrm{u}}\right)(3)$ If we discretize the radius of the granule into 20, we may obtain the mass flux Eq. (4) from Eq. (3) at the surface of the granule as follows 


$$
\begin{aligned}
& \frac{-D_{a b}}{\Delta r}\left(Y_{u, 20}-Y_{u, 19}\right)=k_{u}\left(Y_{u, \infty}-Y_{u, 20}\right) \\
& Y_{u, 20}=\frac{\frac{D a b}{\Delta r} Y_{u, 19}-k_{u} Y_{u, 19}}{\frac{D a b}{\Delta r}+k_{u}}
\end{aligned}
$$

\section{Result and Analysis}

\subsection{Granulation}

From the granulation process in this study, we obtained granules in three different sizes. After drying, the granules are separated by using manual screener into batches smaller than $2 \mathrm{~mm}$, between $3 \mathrm{~mm}$ and $4 \mathrm{~mm}$, and larger than $5 \mathrm{~mm}$. The optimum conditions for the granulation were set before running the granulator. Granulation took time approximately 15 minutes, at speed of the granulator rotation between 400 and 500 RPM. The segregation of the granules in the dish can be seen in Figure 4 below. The larger granules formed are discharged beyond the rim. Binding liquid is sprayed onto incoming fine particles and smaller granules at a spraying zone on the disk.

This observation is similar to the one which have been reported by Diosady, L. L (2003) stated that during the agglomeration, the finer particles settle to the bottom and the largest remain at the top. Because of the size stratification, the product of disk granulation is more uniform in size than of drum granulators, which discharge a mixed product.

\subsection{Effect of granule sizes}

The granular roughness was measured by pressing granules on a balance with the scale of ten kilograms and the result was noted. Table 1 illustrates the crushing strength of the achieved granules in $\mathrm{kg} / \mathrm{cm}^{2}$.
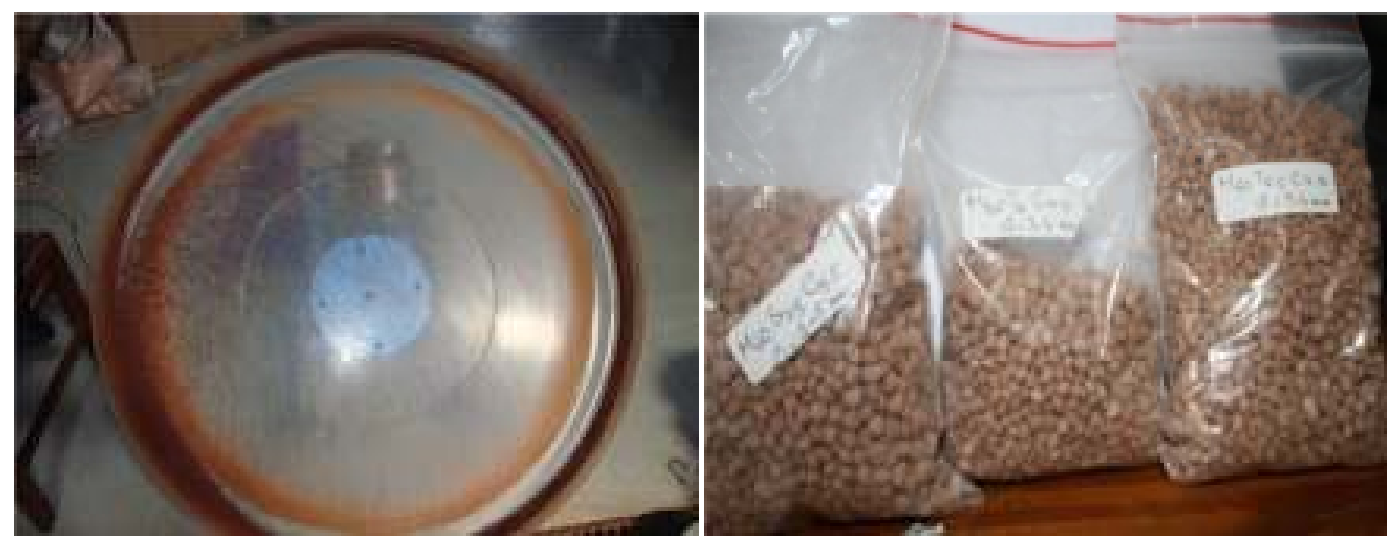

\begin{tabular}{|c|c|c|c|}
\hline \multirow{2}{*}{$\begin{array}{l}\text { Fertilizer } \\
\text { Formula* }\end{array}$} & \multicolumn{3}{|c|}{$\mathrm{Kg} / \mathrm{cm}^{2}$} \\
\hline & $\begin{array}{l}\leq 2 \\
\mathrm{~mm}\end{array}$ & $\begin{array}{l}3-4 \\
\mathrm{~mm}\end{array}$ & $\begin{array}{l}\geq 5 \\
\mathrm{~mm}\end{array}$ \\
\hline $\mathrm{M}_{50} \mathrm{~S}_{10} \mathrm{C}_{7.5}$ & 1.65 & 2.11 & 1.75 \\
\hline $\mathrm{M}_{60} \mathrm{~S}_{10} \mathrm{C}_{7.5}$ & 1.10 & 1.48 & 1.57 \\
\hline $\mathrm{M}_{80} \mathrm{~S}_{10} \mathrm{C}_{7.5}$ & 1.53 & 1.43 & 2.35 \\
\hline $\mathrm{M}_{60} \mathrm{~S}_{1.75} \mathrm{C}_{5}$ & 1.08 & 1.59 & 1.69 \\
\hline $\mathrm{M}_{60} \mathrm{~S}_{1.75} \mathrm{C}_{7.5}$ & 1.29 & 2.00 & 1.64 \\
\hline $\mathrm{M}_{60} \mathrm{~S}_{1.75} \mathrm{C}_{10}$ & 1.34 & 1.28 & 1.69 \\
\hline $\mathrm{M}_{60} \mathrm{~S}_{2} \mathrm{C}_{7.5}$ & 0.72 & 2.87 & 2.20 \\
\hline $\mathrm{M}_{60} \mathrm{~S}_{3} \mathrm{C}_{7.5}$ & 1.32 & 1.60 & 1.48 \\
\hline $\mathrm{M}_{60} \mathrm{~S}_{4} \mathrm{C}_{7.5}$ & 1.32 & 1.38 & 1.56 \\
\hline $\mathrm{M}_{60} \mathrm{~S}_{5} \mathrm{C}_{7.5}$ & 5.25 & 7.93 & $>10$ \\
\hline $\mathrm{M}_{60} \mathrm{~S}_{6} \mathrm{C}_{7.5}$ & 0.56 & 0.76 & 0.94 \\
\hline $\mathrm{M}_{60} \mathrm{~S}_{7.5} \mathrm{C}_{7.5}$ & 2.77 & 3.73 & 4.65 \\
\hline $\mathrm{M}_{60} \mathrm{~S}_{8.5} \mathrm{C}_{7.5}$ & 1.26 & 1.35 & 1.56 \\
\hline
\end{tabular}

Table 1. Crushing strength of granules

We also can take a look at the release profile of the urea in Figure 5. The formula of fertilizer is the same in which is mesh 60 , additive clay of $7.5 \%$, and additive starch of $7.5 \%$ but it is different in granule size. From the release profile in Figure 5, it can be seen that the granular size of smaller than $2 \mathrm{~mm}$, 3-4 $\mathrm{mm}$ and larger than $5 \mathrm{~mm}$ have a very slightly different release rate of $0.186 \%$, $0.167 \%$, and $0.176 \%$, respectively. This percentage was derived from the experiment by dividing total mass of urea in granule sample with total mass of urea release and multiplying with 100 . However, in this case we choose the 3-4 $\mathrm{mm}$ size because it has the smallest release rate. Moreover, the roughness showing in Table 1. also indicates that the suitable size for the good nutrients release is $3-4 \mathrm{~mm}$. Even though the biggest size ( $\geq 5 \mathrm{~mm}$ ) contributes the best granular strength compared to others, in 
Figure 4. Granulation process at optimum conditions and granule view

economic aspects the granule size of 3-4 mm is selected.

\subsection{Effect of mixture (Urea and Zeolite)} mesh on slow release rate

In order to figure out the effect of the particle size of the mixture between urea and zeolite, materials with particle size of $50 ; 60$; and 80 mesh; were used. However, the percentages of clay $(7.5 \%)$, starch $(10 \%)$, and the granule size were the same. Figure 6

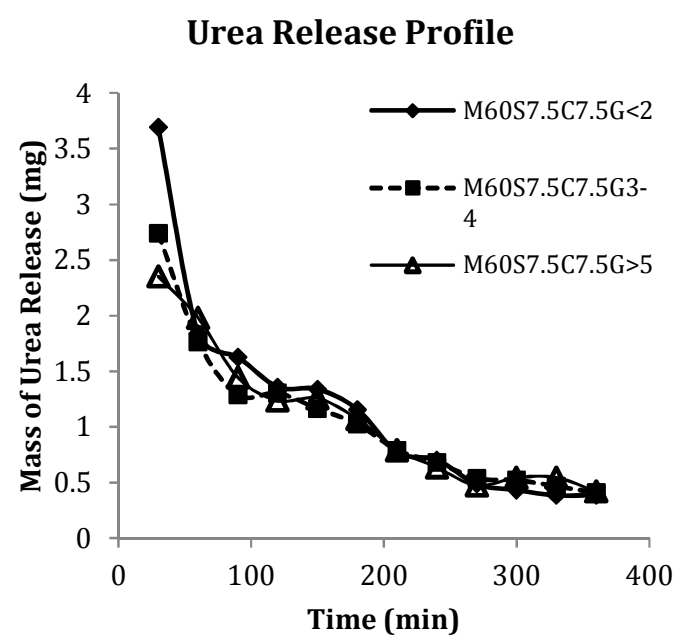

Figure 5. Mass of Urea release $(\mathrm{mg} / 16 \mathrm{~g}$ granules)

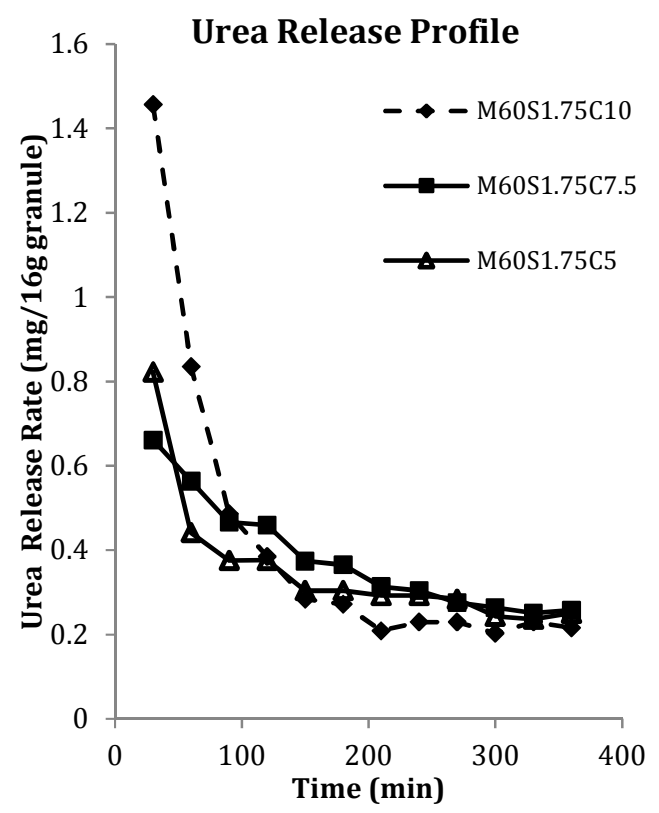

Figure 7. Mass of Urea release $(\mathrm{mg} / 16 \mathrm{~g}$ demonstrates that 50 and 80 mesh granules produced a rate of similar release rates at $0.295 \%$ and $0.275 \%$, whereas the 60 -mesh granule produced a release rate only $0.208 \%$.

3.4. Effect of clay addition on the slow release rate

To predict the effect of clay additive to the release rate, the similar way to the two cases above was derived. This means that the particle size was bent at 60-mesh, the

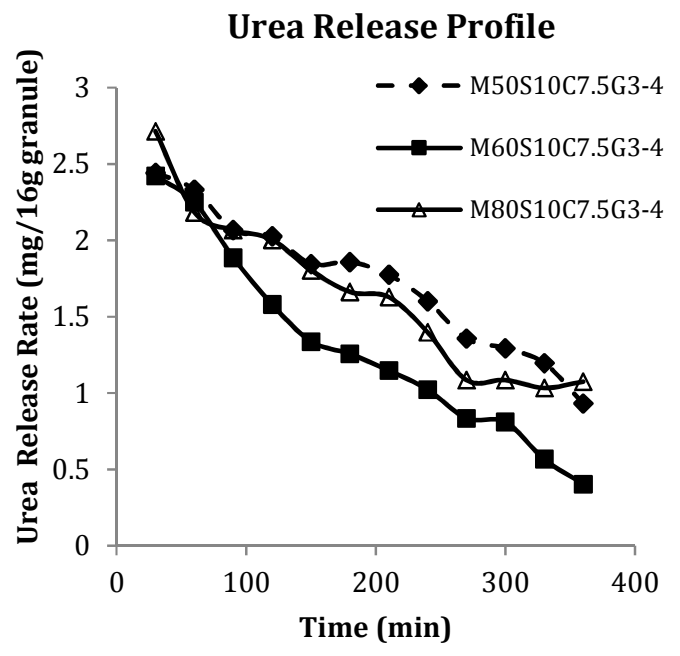

Figure 6. Mass of Urea release $(\mathrm{mg} / 16 \mathrm{~g}$ granules)

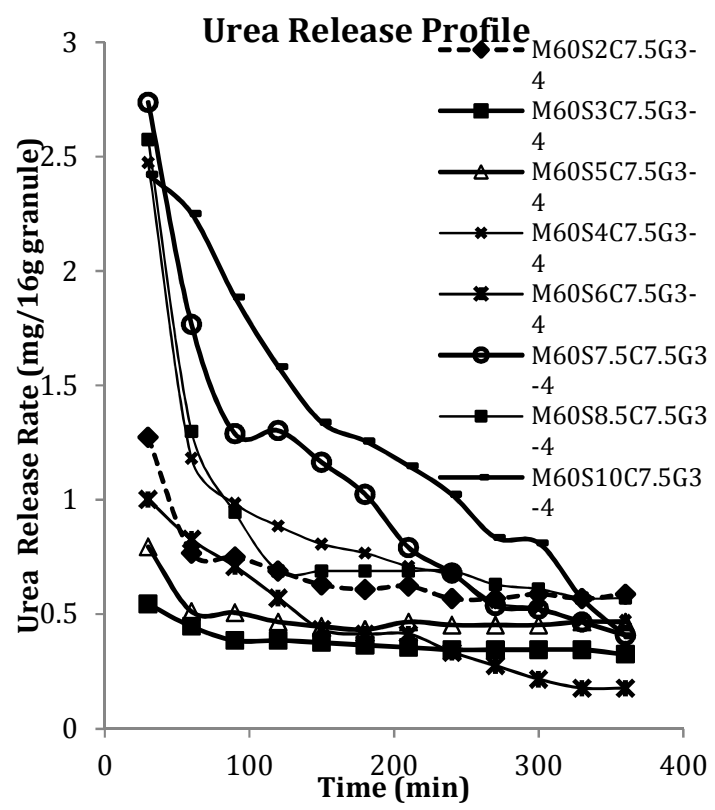

Figure 8. Mass of Urea release $(\mathrm{mg} / 16 \mathrm{~g}$ 


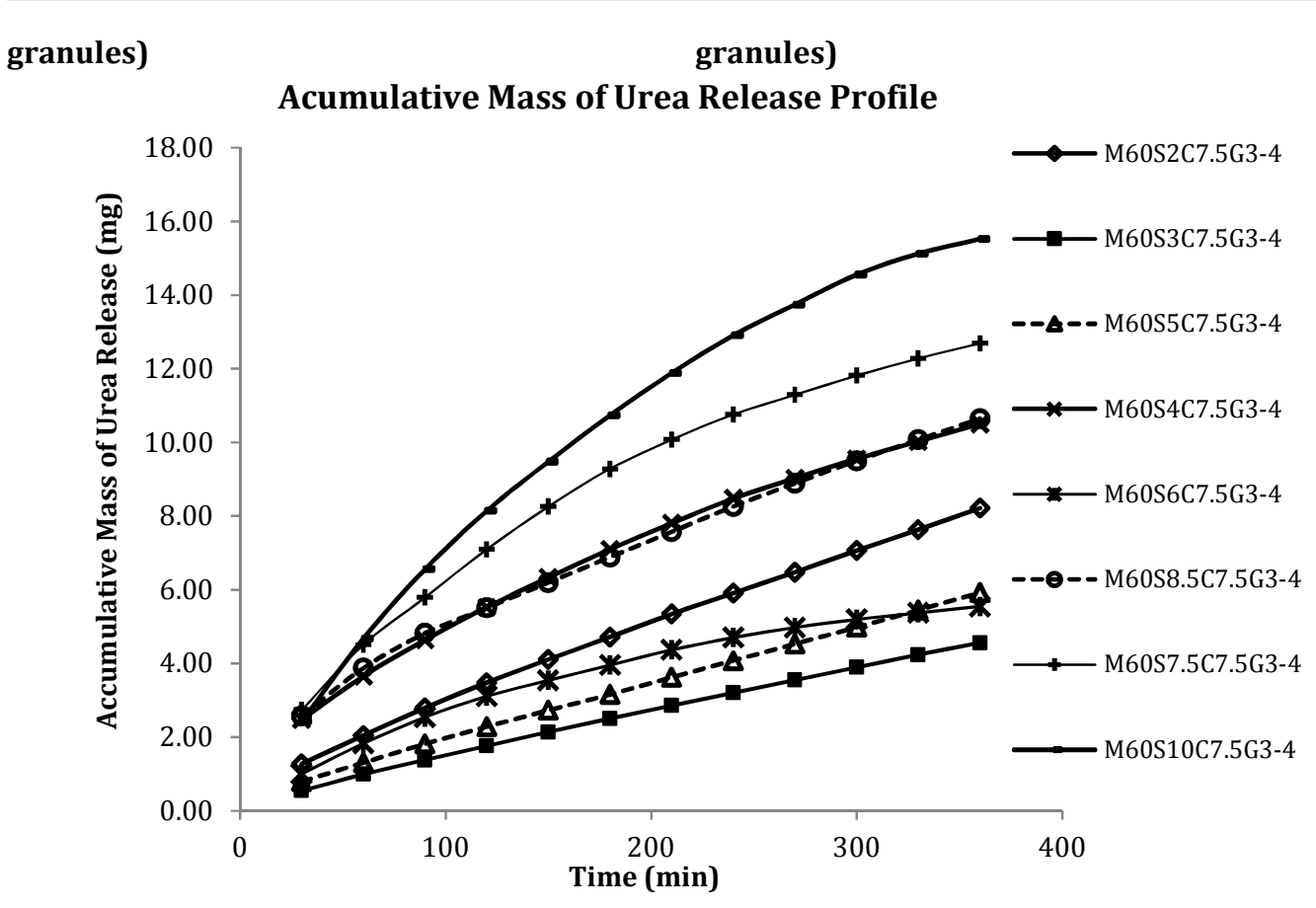

Figure 9. Accumulative mass of Urea release (mg)

concentration of starch at $1.75 \%$, and the granule size at 3-4 $\mathrm{mm}$, but with a variation of clay concentration such as the following $5 \%, 7.5 \%$, and $10 \%$. There is a very slight different in nutrients release rate between $\mathrm{M}_{60} \mathrm{~S}_{1.75} \mathrm{C}_{5}$ and $\mathrm{M}_{60} \mathrm{~S}_{1.75} \mathrm{C}_{7.5}$ formulating in Figure 7 which are $0.052 \%$ and $0.59 \%$, respectively; in contrast, the nutrients release rate of $\mathrm{M}_{60} \mathrm{~S}_{1.75} \mathrm{C}_{10}$ is $0.068 \%$. We may conclude that the best nutrients release rate among them is $0.052 \%$ which stands for $\mathrm{M}_{60} \mathrm{~S}_{1.75} \mathrm{C}_{7.5}$. Hongprayoon et al. (1991) reported that the high-urea-adsorption was high in organic $\mathrm{C}$ and 2:1 clay minerals.

Clay is not only good due to high urea adsorption capacity but also it is added to damp powders to enable a stronger agglomeration in a tumbling agitating granulator (Putrawan, 2003).

\subsection{Effect of starch content in binder on slow release rate}

The effect of starch concentration in binder solution on release rate was studied at eight concentration values, $2 \%, 3 \%, 4 \%, 5 \%, 6 \%$, $7.5 \%, 8.5 \%$, and $10 \%$; while the variables such as particle size, percentages of clay additive, and granule size were remained constant. As indicated in Figure 8, the lowest release rate is $\mathrm{M}_{60} \mathrm{~S}_{3} \mathrm{C}_{7.5} \mathrm{G}_{3-4}$ which is just $0.063 \%$ whereas the highest is $0.176 \%$ for $\mathrm{M}_{60} \mathrm{~S}_{7.5} \mathrm{C}_{7.5} \mathrm{G}_{3-4}$. However, experiments also indicated that the starch percentage of $4 \%$, $7.5 \%, 8.5 \%$, and $10 \%$, the release rate rapidly decreased at the first few hours and then almost remained stable after that, while the others have slightly decreased then almost steady release. The release rates of these formulations are $0.106 \%, 0.063 \%, 0.141 \%$, $0.073 \%, \quad 0.073 \%, 0.176 \%, 0.154 \%$, and $0.108 \%$, respectively.

Zhang, F et al. (2005) showed that nitrogen release rate of fertilizer coated by plastic-starch composites were the lowest compared to the other chemical materials. Figure 9 indicates the accumulative mass of urea release and these releases can be proportionally estimated to be more than three months.

From the conclusion of each variable above, we may briefly summarize that the most suitable formula among those is the one containing the 60-mesh mixture, clay addition of $7.5 \%, 3 \%$ of starch addition in binder solution and 3-4 mm of granule size, designated the M60S3C7.5G3-4. Therefore, the gradient of mass fraction of urea release can be studied from this formula as can be seen in Figure 10.

The gradient of mass fraction of urea release is shown in Figure 10. As long as the release time increases, we can see that the 
gradient is decreased from 0.07 to 0.04 for the period of time 6 hours. The average of this mass fraction is 0.043 with the standard deviation of \pm 0.015 which is in the range of 0.028 to 0.058 . This result will be used to compare with the result from the simulation program which will be indicated in the next session.

\subsection{Release Modeling}

The simulation study is carried out using the MATLAB computational program version 7.8.0 (R2009a). The results from this simulation for mass fraction release of urea and accumulative mass fraction of urea release are shown in Figure 11 and Figure 12, respectively. Figure 11 demonstrates the profile of mass fraction of urea release from the outer of the granule which means at the $\mathrm{r}=\mathrm{R}$.

It also can be seen from Figure 11 that mass fraction of urea release is continuously decreased as long as the release time is increased. This is because when the granule is in contact with water, urea starts to release gradually. With the mass fraction of 0.5 , the release of urea can retain until 0.055 after three months.

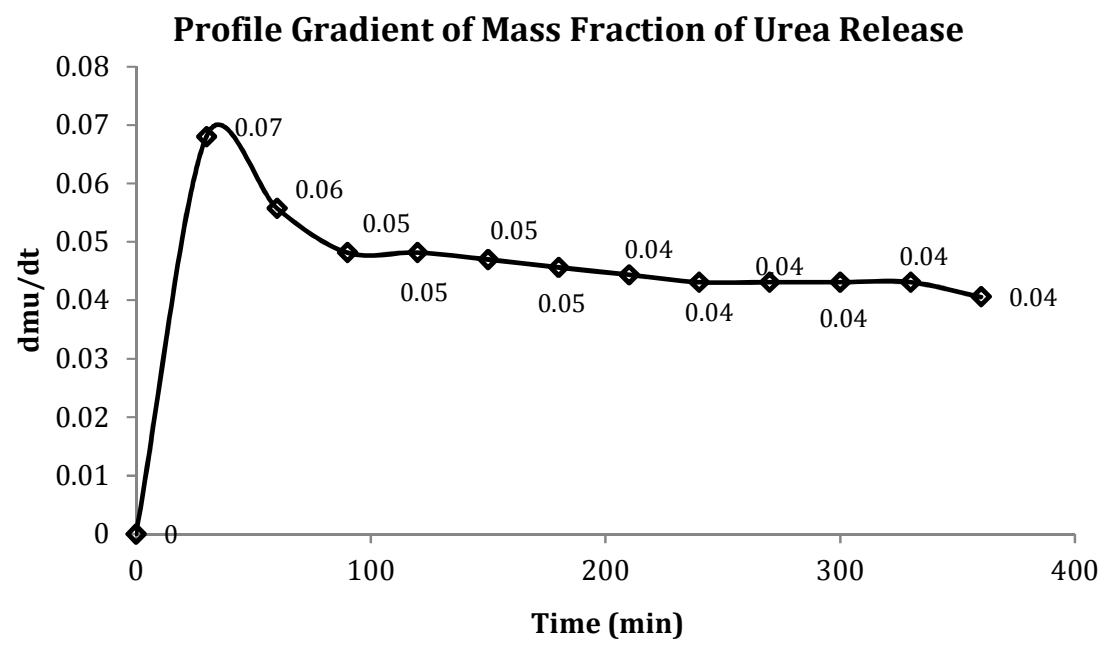

Figure 10. Profile of gradient of mass fraction of Urea release

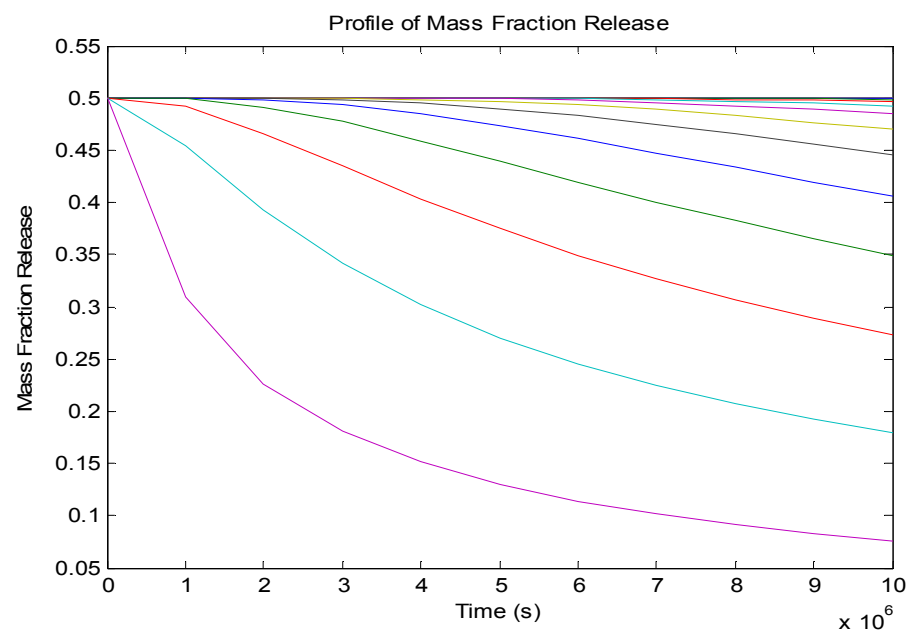

Figure 11. Mass fraction release of Urea 


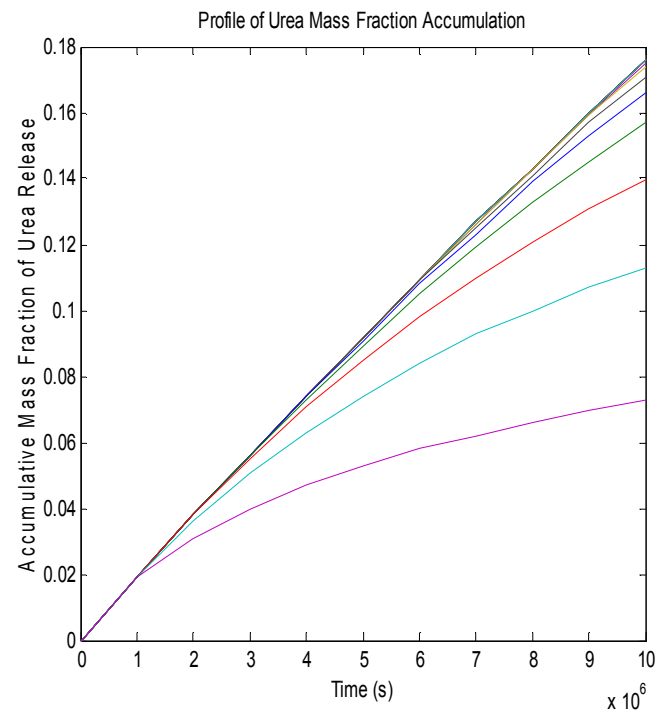

Figure 12. Accumulative mass fraction of Urea release

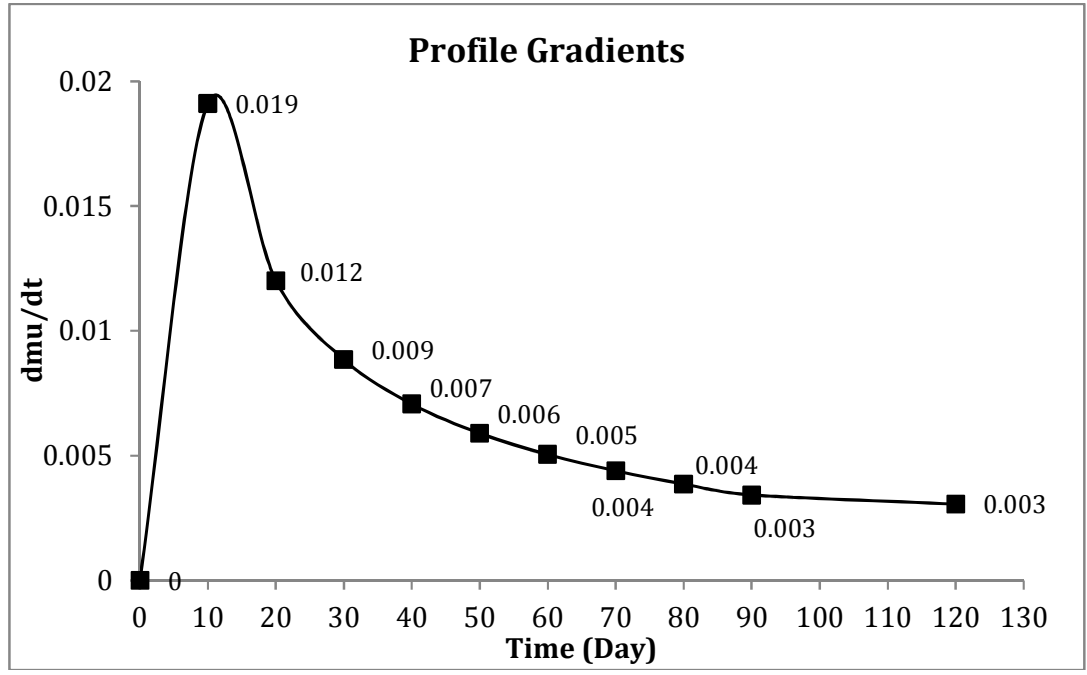

Figure 13. Profile of mass fraction gradient

It can be seen in Figure 12 that the lowest accumulative mass fraction of urea release is just 0.073 for the release time of three months. This means that from the mass fraction of urea of 0.5 or $0.035 \mathrm{mg} /$ granule will remain 0.073 or $0.0051 \mathrm{mg} /$ granule after the period of three months.

Figure 13 shows that in the period of three months, the gradient is just slightly decreased. The mass fraction gradient starts from 0.019 and this is reduced continuously until 0.003 after 3 months. The average of mass fraction is $0.007 \pm 0.005$. This means that the value of mass fraction of urea release is in the range of 0.0014 to 0.012 . The comparison between these results with the experiment results shown in Figure 10 is not too much different. The release of urea in the experiment in the range of 0.028 to 0.058 is faster than in the release from the simulated program. This may be because the zeolite used in this study is not in good quality. The result from the experiment shown the quality of zeolite contains mostly in quartz, almite and calcite.

\section{Conclusion}

The granule size of $3-4 \mathrm{~mm}$ is selected to be the best one among the variation sizes in this study because of its benefits. According to the slow release rate as well as the economic aspects, mesh 60 of the mixture 
between urea and zeolite is chosen. The percentage of clay addition in the granulation process is $7.5 \%$. The percentage of starch addition in binder solution of $3 \%$ indicated the slowest nutrient release from the granule so that the most suitable formula is $\mathrm{M}_{60} \mathrm{~S}_{3} \mathrm{C}_{7.5} \mathrm{G}_{3-4}$. It is proportionally defined that the release time of nutrient from experiment and from simulated program is at least for three months.

\section{References}

Ariyathilaka, G. A. M. C.; Buddhika, A. N.; Kahatapitiya, K. R. M. G.; Karunarathana, K. D. N.; Urea Manufacturing Plant, Sri Lanka, 2008; 2-30.

Bojic, J.; Radovanovic, B.; Dimitrijevic, J. Spectrophotometric determination of urea in dermatologic fromulations and cosmetics. Journal of the Japan Society for Analysis Chemistry. 2008, 24(6), 769-774.

Devotta, S.; Juwarkar, A. A.; Labhasetwar, N. K.; Rayalu, S. S.; Bansiwal, A. K. Surfactantmodified zeolite as a slow release fertilizer for phosphorus. Journal of Agricultural and Food Chemistry. 2006, 54(13), 4773-4779.

Diosady, L. L. Pan Granulator: Final Technical on Fortification of Salt; Department of Chemical Engineering and Applied Chemistry: Canada, 2003.

Eberl, D. D. Controlled-Release Fertilizers Using Zeolite, U.S. Department of the Interior, U.S. Geological Survey, (http://infohouse.p2ric.org/ref/01/00591.p df).

Leggo, P. J.; Ledesert, B. Organo-zeolitic-soil system: a new approach to plant nutrition. Journal of Nova Science Publisher, Inc. 2009.
Maryland, B. Cambodian Agriculture Sector Diagnostic Report; Agrifood Consulting International and CamConsult, 2006; 45.

Millan, G.; Agosto, F.; Vazquez, M.; Botto, L. Use of clinoptilolite as a carrier for nitrogen fertilizers in soils of the pampean regions of argentina. Journal of Cienciae Investigacion AGRARIA. 2008, 35(3), 245-254.

Mumpton, F. A. Uses of natural zeolite in agriculture and industry. Paper of National Academy of Sciences Colloquium, Canada, 1999, 96(7), 3436-3470.

Mund.; Peter. J.; Bunthan. N. Present Situation and Future Perspective of Cambodian Agriculture. Conference on International Agricultural Research for Development, Cambodia, 2006.

Perez-Caballero, R.; Gil, J.; Benitez, C.; Gonzalez, J. L. The effect of adding zeolite to soils in order to improve the N-K nutrition of olive trees. Preliminary results, American Journal of Agricultural and Biological Sciences, 2008, 2(1), 321-324.

Polat, E.; Karaca, M.; Demir, H.; Onus, A. N. Use of natural zeolite (clinoptilolite) in agriculture. Journal of Fruit and Ornamental Plant Research. 2004, 12, 183-189.

Putrawan, I. D. G. A. Granulation Practice; Chemical Engineering Department ITB: Bandung, 2003.

Zhang, F.; Wang, R.; Xiao, Q.; Wang, Y.; Zhang, J. Effects of slow/controlled-release fertilizer cemented and coated by nano-materials on biology. Institute of Agricultural Resources and Regional Planning, Chinese Academy of Agricultural Sciences. 2005, 11(1), 18-26. 